\title{
Atmospheric mercury in the Southern Hemisphere tropics: seasonal and diurnal variations and influence of inter-hemispheric transport
}

\author{
Dean Howard ${ }^{1}$, Peter F. Nelson ${ }^{1}$, Grant C. Edwards ${ }^{1}$, Anthony L. Morrison ${ }^{1}$, Jenny A. Fisher ${ }^{2,3}$, Jason Ward ${ }^{4}$, \\ James Harnwell ${ }^{4}$, Marcel van der Schoot ${ }^{4}$, Brad Atkinson ${ }^{5}$, Scott D. Chambers ${ }^{6}$, Alan D. Griffiths ${ }^{6}$, \\ Sylvester Werczynski ${ }^{6}$, and Alastair G. Williams ${ }^{6}$ \\ ${ }^{1}$ Department of Environmental Sciences, Macquarie University, Sydney, New South Wales, 2109, Australia \\ ${ }^{2}$ Centre for Atmospheric Chemistry, School of Chemistry, University of Wollongong, Wollongong, \\ New South Wales, 2552, Australia \\ ${ }^{3}$ School of Earth \& Environmental Sciences, University of Wollongong, Wollongong, New South Wales, 2552, Australia \\ ${ }^{4}$ Oceans and Atmosphere Flagship, Commonwealth Science and Industrial Research Organisation, \\ Aspendale, Victoria, 3195, Australia \\ ${ }^{5}$ Darwin Research Station, Bureau of Meteorology, Darwin, Northern Territory, 0810, Australia \\ ${ }^{6}$ Institute for Environmental Research, Australian Nuclear Science and Technology Organisation, \\ Sydney, New South Wales, 2232, Australia
}

Correspondence to: Dean Howard (dean.howard@mq.edu.au)

Received: 3 April 2017 - Discussion started: 21 April 2017

Revised: 29 July 2017 - Accepted: 21 August 2017 - Published: 28 September 2017

\begin{abstract}
Mercury is a toxic element of serious concern for human and environmental health. Understanding its natural cycling in the environment is an important goal towards assessing its impacts and the effectiveness of mitigation strategies. Due to the unique chemical and physical properties of mercury, the atmosphere is the dominant transport pathway for this heavy metal, with the consequence that regions far removed from sources can be impacted. However, there exists a dearth of long-term monitoring of atmospheric mercury, particularly in the tropics and Southern Hemisphere. This paper presents the first 2 years of gaseous elemental mercury (GEM) measurements taken at the Australian Tropical Atmospheric Research Station (ATARS) in northern Australia, as part of the Global Mercury Observation System (GMOS). Annual mean GEM concentrations determined at ATARS $\left(0.95 \pm 0.12 \mathrm{ng} \mathrm{m}^{-3}\right)$ are consistent with recent observations at other sites in the Southern Hemisphere. Comparison with GEM data from other Australian monitoring sites suggests a concentration gradient that decreases with increasing latitude. Seasonal analysis shows that GEM concentrations at ATARS are significantly lower in the distinct wet monsoon season than in the dry season. This result provides insight into alterations of natural mercury cycling processes as a re-
\end{abstract}

sult of changes in atmospheric humidity, oceanic/terrestrial fetch, and convective mixing, and invites future investigation using wet mercury deposition measurements. Due to its location relative to the atmospheric equator, ATARS intermittently samples air originating from the Northern Hemisphere, allowing an opportunity to gain greater understanding of inter-hemispheric transport of mercury and other atmospheric species. Diurnal cycles of GEM at ATARS show distinct nocturnal depletion events that are attributed to dry deposition under stable boundary layer conditions. These cycles provide strong further evidence supportive of a "multihop" model of GEM cycling, characterised by multiple surface depositions and re-emissions, in addition to long-range transport through the atmosphere.

\section{Introduction}

Mercury (Hg) is a toxic element that has natural and anthropogenic sources, sinks, and cycles within the environment. Human activities such as gold mining and biomass/fossil fuel combustion have perturbed the natural cycling of mercury through the addition of mercury emissions, which are re- 
deposited from the atmosphere to land, vegetation, and water bodies. It is estimated that currently anthropogenic emissions to the atmosphere increase the global atmospheric mercury pool by $1960 \mathrm{t}$ annually, a value that represents $30 \%$ of estimated mercury emissions, with the remainder emitted from natural geological sources $(10 \%)$ or re-emitted from stores of previously deposited mercury $(60 \%)$. These mercury emission estimates are subject to large uncertainties (Arctic Monitoring and Assessment Programme/United Nations Environment Programme, 2013; United Nations Environment Programme, 2013). That anthropogenic mercury sources now exceed those from natural sources on a global scale is of concern for both human and environmental health. Evidence suggests these additional sources are leading to increased concentrations of mercury in the oceans and in marine animals, with the consequence that bioaccumulation of toxic methylmercury within aquatic food chains has also increased (Mason et al., 2012; United Nations Environment Programme, 2013). There exists a significant pathway for methylmercury transfer to humans, as it is estimated that more than $100 \mathrm{Mt}$ of fish are eaten worldwide each year and fish provide 2.5 billion people with at least $20 \%$ of their protein intake. Mercury in this latter form can seriously threaten human health through impacts on the development of foetuses and young children. In response to this threat, the United Nations Environment Programme (UNEP) has developed the Minamata Convention on Mercury, which is expected to be ratified in 2017.

The global cycling of mercury is unique amongst metals, as within Earth's atmosphere 90 to $99 \%$ of mercury is found as gaseous elemental mercury (GEM), with the remaining portion composed of operationally defined gaseous oxidised mercury (GOM) and particulate-bound mercury (PBM) collectively known as reactive mercury (RM) (Gustin et al., 2013). The low atmospheric reactivity and low solubility of the elemental form (GEM) results in low wet/dry deposition rates and scavenging of GEM from the atmosphere. These attributes result in atmospheric transport being the dominant distribution mechanism through the environment, with long-range transport possible across hemispheric scales. Differences in background atmospheric mercury concentrations between the hemispheres are hence dependent on emission rates, deposition rates, inter-hemispheric transport processes, and atmospheric mercury lifetimes. The atmospheric lifetime is defined here as the mean time after emission that GEM is removed from the atmosphere (Lindberg et al., 2007) and is estimated from mass-balance approaches utilising hemispheric background concentration and source/sink data (e.g. Slemr et al., 1985). The atmospheric lifetime of GEM is currently estimated at 5-12 months (Holmes et al., 2006, 2010; Selin et al., 2007; Horowitz et al., 2017).

With $68 \%$ of the Earth's landmass and $88 \%$ of the human population in the Northern Hemisphere $(\mathrm{NH})$, both natural and anthropogenic emissions of mercury are disproportionately distributed between the hemispheres. Towards the equator, the existence of the Intertropical Convergence Zone (ITCZ) and the associated upward/poleward movement of the Hadley circulation leads to reduced tropospheric mixing across the atmospheric or chemical equator (Bowman and Cohen, 1997; Hamilton et al., 2008; Holmes and Prather, 2017) and hence a broad, hemispheric gradient of GEM concentrations (Slemr et al., 1985; Sprovieri et al., 2016). Stationary observations of GEM within the tropics are rare but those that are available report significant changes in concentration as source regions shift across hemispheres with the drift of the atmospheric equator (Müller et al., 2012; Wang et al., 2014). The tropics also represent an important region for mercury cycling as they are home to around $40 \%$ of the world's population, including over $50 \%$ of people under the age of 15, a group at greater risk of adverse effects due to mercury exposure during early development (BoseO'Reilly et al., 2010). Furthermore, this region hosts several large coastal communities within emerging and developing economies, in which environmental controls and advisories are not always well developed (Costa et al., 2012).

Characterisation of background GEM in the tropics and Southern Hemisphere (SH) has been hindered by a lack of observations and is based largely on intermittent ship voyages (Soerensen et al., 2012, 2014), along with a few longterm stationary records in South America, Africa, Antarctica, and islands in the Indian and eastern Pacific oceans (Sheu et al., 2010; Müller et al., 2012; Wang et al., 2014; Angot et al., 2014, 2016; Slemr et al., 2015). A recent comparison of interannual records from four mercury monitoring stations spanning a latitude range of $34-72^{\circ} \mathrm{S}$, of which the longestrunning spans 7 years, suggests that background GEM concentrations in the $\mathrm{SH}$ are between 0.85 and $1.05 \mathrm{ng} \mathrm{m}^{-3}$ (Slemr et al., 2015). Previous measurements of atmospheric mercury concentrations have also been reviewed by Sprovieri et al. (2010, 2016). The Australian continent, with its large non-Antarctic SH landmass (22\%), a latitudinal distribution $\left(11-44^{\circ} \mathrm{S}\right)$ spanning diverse climatic zones, and a mercury emission profile characterised by anthropogenic sources that are significantly smaller than natural and re-emitted sources (Nelson et al., 2012), presents unique opportunities for extending environmental mercury monitoring in a region that has largely been under-represented.

Initiated under the Global Mercury Observation System (GMOS) and considered for inclusion with the Asia Pacific Mercury Monitoring Network (APMMN), measurements of GEM are being undertaken at the Australian Tropical Atmospheric Research Station (ATARS), northeast of Darwin in Australia's Northern Territory. Of the six GMOS sites classed as tropical, ATARS is the southernmost and one of only two (along with Kodaicanal; $10.2314^{\circ} \mathrm{N}, 77.4652^{\circ} \mathrm{E}$ ) situated in the Eastern Hemisphere. This site is therefore important in bridging the spatial gap in GEM measurements in equatorial regions around the globe. Originally an experimental radar site, ATARS was expanded in 2010 to incorporate greenhouse gas measurements as part of the Australian 
Greenhouse Gas Observation Network (Ziehn et al., 2016) and is operated jointly by the Australian Bureau of Meteorology (BoM) and the Commonwealth Science and Industrial Research Organisation (CSIRO). The Australian Nuclear Science and Technology Organisation (ANSTO) began continuous atmospheric radon measurements at the site in 2012 to aid in the determination of terrestrial influence on observed air masses (Chambers et al., 2016b). In June 2014, an additional expansion took place and now continuous aerosol, reactive gas $\left(\mathrm{O}_{3}, \mathrm{NO}_{x}\right)$, and GEM measurements complement the suite of atmospheric measurements at the site (Mallet et al., 2016). This GEM dataset represents the first multiyear time series of atmospheric mercury monitoring in tropical Australia.

We present here the first 2 years of tropical GEM measurements from ATARS, examine their seasonal and diurnal variations, and evaluate the contribution of air masses transported from the $\mathrm{NH}$ to the observed concentrations. These results add substantial new information to our understanding of mercury in the SH and tropical atmosphere.

\section{Methods}

\subsection{Site description}

ATARS is situated on the Gunn Point peninsula $\left(12.2491^{\circ} \mathrm{S}\right.$, $131.0447^{\circ} \mathrm{E}$; Fig. 1), approximately $20 \mathrm{~km}$ northeast from the suburban edge of Darwin (2013 population 136200 ; Australian Bureau of Statistics, 2015) in Australia's Northern Territory. Between 2 and $9 \mathrm{~km}$ to the north and west of ATARS lies the edge of the peninsula that gives way to the Tiwi Islands and Timor Sea, whilst the land to the east and south is largely uninhabited and includes national parks and conservation areas.

The climate in the region is best described as tropical (Köppen category Aw, as reported by Peel et al., 2007) with mean monthly maximum temperatures between 30 and $33^{\circ} \mathrm{C}$ (1941 to 2016 means; Australian Bureau of Meteorology, 2016) and a distinct monsoon (wet) season that coincides generally with the austral summer (December-February). The build-up to these monsoon seasons is characterised by steadily increasing minimum temperatures $\left(19^{\circ} \mathrm{C}\right.$ in July to $25^{\circ} \mathrm{C}$ in December) and associated increases in relative humidity (daily ranges of $37-60 \%$ in July to $72-83 \%$ in February). Mean annual rainfall is $1728 \mathrm{~mm}$, with an average of $1604 \mathrm{~mm}(>90 \%)$ of this falling in the period NovemberApril. As the site is located on a peninsula, a sea-land breeze cycle is often experienced in the dry season, resulting in mostly southeasterly winds throughout the morning, tending northerly as the sea breeze circulation sets in from the nearby coast. In the wet season, shifting synoptic patterns result in an increased frequency of westerly winds.

The vegetation classification is savannah with coarse grasses and scattered tree growth immediately surrounding

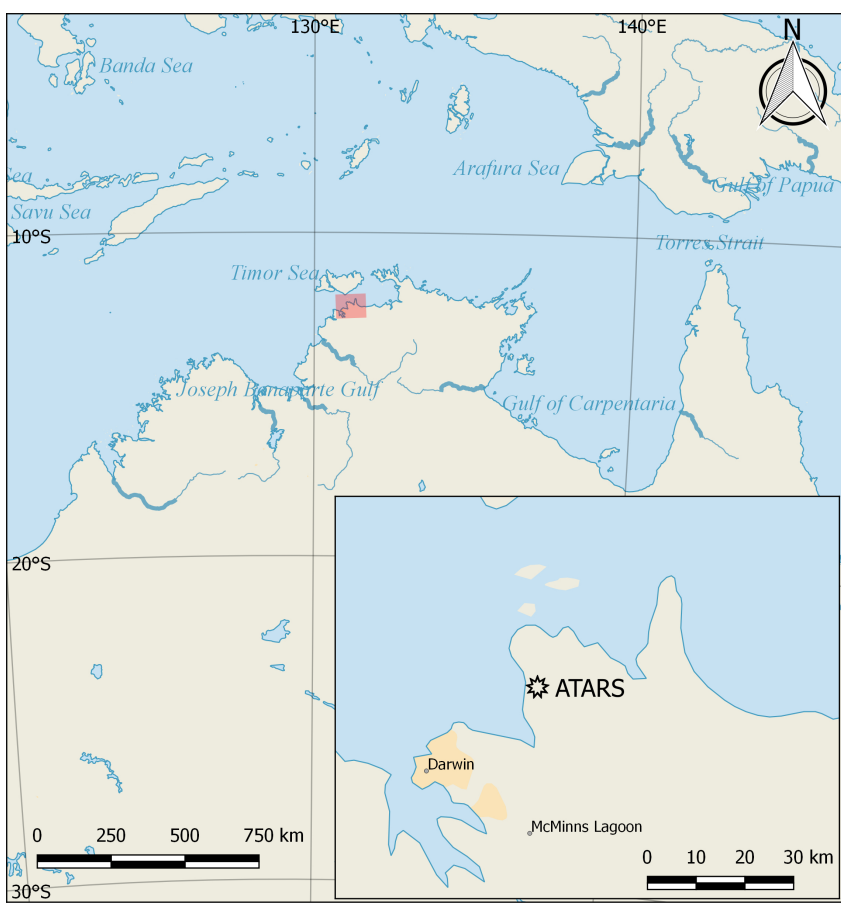

Figure 1. Map of region surrounding ATARS. Composed in QGIS using Natural Earth dataset.

the site. Burning of the grassed areas occurs frequently, with a fire return interval of 1-2 years. Direct mercury analysis (see Edwards and Howard, 2013, for methodology) of vegetation within $500 \mathrm{~m}$ of the station gave total mercury concentrations of $7.23 \pm 0.37 \mu \mathrm{g} \mathrm{kg}^{-1}(n=18)$ for grass and $21.09 \pm 3.79 \mu \mathrm{g} \mathrm{kg}^{-1}(n=9)$ for tree litter. Sampling of soils in the same locations gave total mercury concentrations of $9.14 \pm 0.58 \mathrm{\mu g} \mathrm{kg}^{-1}(n=18)$ in grassed areas and $26.49 \pm 3.31 \mathrm{\mu g} \mathrm{kg}^{-1}(n=9)$ under forest canopy, confirming that soils in the area are categorised as background (>100 $\mathrm{g} \mathrm{kg}^{-1}$; Gustin et al., 2006). Sampling was undertaken in the early dry season, approximately 10-12 months after the last grass fire.

Anthropogenic emissions of mercury and its compounds to the atmosphere in and around Darwin are generally quite low. Australian National Pollutant Inventory (NPI) data for 2014-2015 state that six sites situated between 20 and $40 \mathrm{~km}$ from ATARS in the direction of Darwin (wind directions 190 to $240^{\circ}$ ) emitted a total of $0.12 \mathrm{~kg} \mathrm{Hg}$ to the atmosphere (Australian National Polluntant Inventory, 2016). Other distributed anthropogenic mercury emissions in Darwin are estimated at less than $0.2 \mathrm{~kg} \mathrm{a}^{-1}$, based on $25 \mathrm{~km} \times 25 \mathrm{~km}$ gridded population data (Nelson et al., 2012).

\subsection{Measurements}

Continuous ( 5 min sample) GEM measurements were obtained using a Tekran 2537X Automated Ambient Air Analyser (2537X). This instrument is housed in an air- 
conditioned structure with internal temperature set at $25^{\circ} \mathrm{C}$. Air is sampled from a $10 \mathrm{~m}$ high tower through $7.95 \mathrm{~mm}$ I.D. perfluoroalkoxy tubing using a Thomas 2688 vacuum pump drawing approximately $50 \mathrm{~L} \mathrm{~min}^{-1}$ (residence time $0.6 \mathrm{~s})$. The $2537 \mathrm{X}$ subsamples from this flow at $1 \mathrm{~L} \mathrm{~min}^{-1}$ through $6 \mathrm{~m}$ of heated polytetrafluoroethylene (PTFE) line maintained at $50^{\circ} \mathrm{C}$, and two $0.2 \mu \mathrm{m}$ PTFE filters positioned before and after the heated line. The $2537 \mathrm{X}$ operates on the principle of cold vapour atomic fluorescence spectroscopy (CVAFS) following gold amalgamation preconcentration (see for example Ebinghaus et al., 1999; Munthe et al., 2001). This technique quantifies total gaseous mercury $(\mathrm{TGM}=\mathrm{GEM}+\mathrm{GOM})$; however, experience from other researchers suggests that the fraction of GOM in the atmosphere is generally small and removed upstream of the 2537X. As such we present the results here as GEM and not TGM, in line with reporting standards employed by other GMOS secondary sites (Sprovieri et al., 2016). Reference volumes are reported at $1 \mathrm{~atm}$ and $0{ }^{\circ} \mathrm{C}$.

Quality assurance and quality control procedures were applied as per protocols derived for GMOS sites (Sprovieri et al., 2016). Calibration of the $2537 \mathrm{X}$ took place every $23 \mathrm{~h}$ using an internal mercury permeation source maintained at $50^{\circ} \mathrm{C}$. Primary calibration of this source took place twice each year using manual injections of mercury vapour. No change in the internal source permeation rate was detected over this period. Furthermore, standard additions of mercury are automatically introduced to the $2537 \mathrm{X}$ from the internal permeation source every 35 samples $(\sim 3 \mathrm{~h})$ in order to verify GEM recovery performance.

Continuous hourly measurements of radon were sampled at $12 \mathrm{~m}$ using an ANSTO-designed and built, $700 \mathrm{~L}$ dualflow-loop two-filter radon detector (Whittlestone and $\mathrm{Za}$ horowski, 1998; Chambers et al., 2011). This detector samples at $40 \mathrm{~L} \mathrm{~min}^{-1}$ through $25 \mathrm{~mm}$ high-density polyethylene agricultural pipe and has a lower limit of detection of 40 $50 \mathrm{mBq} \mathrm{m}^{-3}$. Calibrations are performed monthly by injecting radon from a $101.15 \pm 4 \% \mathrm{kBq}{ }^{226} \mathrm{Ra}$ source (delivering $12.745 \mathrm{~Bq}^{222} \mathrm{Rn} \mathrm{min}^{-1}$ ), traceable to NIST standards. Instrumental background is checked every 3 months. Radon measurements were corrected for the response time of the instrument (Griffiths et al., 2016), although the main trends were not affected by this time correction. Time-corrected radon data were then split into "fetch" and "diurnal" components by interpolating between minimum afternoon (12:00 to 17:00) values when atmospheric mixing is greatest and subtracting these interpolated values (fetch component) from the original signal, leaving the diurnal component (see Chambers et al., 2016a, for details).

Meteorological measurements are collected at ATARS using a standard automated weather station (AWS) operated by the Australian Bureau of Meteorology. Precipitation data were collected using a $203 \mathrm{~mm}$ tipping bucket rain gauge and daily totals were summed to give cumulative season totals centred around a hydrologic year beginning 1 June. The tem- poral extents of what we define here as "wet seasons" were then determined using the method of Smith et al. (2008), whereby 15 and $85 \%$ of the total cumulative rainfall marked their onset and conclusion, respectively. The wet season of 2014-2015 was further extended to include two $>100 \mathrm{~mm}$ rain events that took place in November and March.

\subsection{Modelling}

As the atmospheric equator changes its position relative to the geographic equator, we employed a system of passive tracers within the GEOS-Chem chemical transport model to help assess the impact of air originating from the $\mathrm{NH}$ on the site, based on the work of Holmes and Prather (2017). We use GEOS-Chem v10-01 driven by assimilated meteorology from the NASA Goddard Earth Observing System Forward Processing (GEOS-FP) data product, run at $2^{\circ} \times 2.5^{\circ}$ horizontal resolution and 47 vertical levels from the surface to $0.01 \mathrm{hPa}$. Tracers with 90 -day lifetimes were uniformly released from the surface in all model boxes poleward of $45^{\circ}$ latitude within each hemisphere. The atmospheric equator is then defined as the point where mixing ratios of tracers from the two hemispheres are equal. Tracer concentrations in surface air over ATARS were saved as daily mean values in the model grid box containing the site $\left(2^{\circ}\right.$ latitude by $2.5^{\circ}$ longitude and an approximate atmospheric depth of $130 \mathrm{~m}$ ). Increasing the number of grid squares over which tracer values were averaged did not significantly affect the results.

The NOAA Hybrid Single Particle Lagrangian Integrated Trajectory (HYSPLIT) model (Draxler, 1999; Draxler and Hess, 1998; Stein et al., 2015) was also employed to assess influences of air mass source regions. Global Data Assimilation System (GDAS) $0.5^{\circ}$ meteorological reanalysis data were used to drive the model, and trajectories were initialised at 0.5 times the mixed layer height as determined by HYSPLIT. To reduce the influence of local daily variation in GEM concentrations on this analysis, back trajectories were calculated for each hour of the day rather than as a daily or part-daily mean. For each trajectory, air parcel coordinates were calculated every $2 \mathrm{~h}$ and weighted per the corresponding GEM concentration. These weighted values were then averaged over $0.5^{\circ} \times 0.5^{\circ}$ grid cells.

\section{Results and discussion}

\subsection{Overall means and seasonal trends}

Measurements of GEM at ATARS began on 5 June 2014 and were still ongoing at the time of writing. Instrument maintenance/downtime plus application of QC protocols, including calibration and standard additions, resulted in $68.1 \%$ temporal measurement coverage during the first 2 years of operation (Fig. 2, Table 1). Concentrations are normally distributed across this period with an overall mean of $0.95 \pm 0.12 \mathrm{ng} \mathrm{m}^{-3}(n=130312)$, which is within the range 


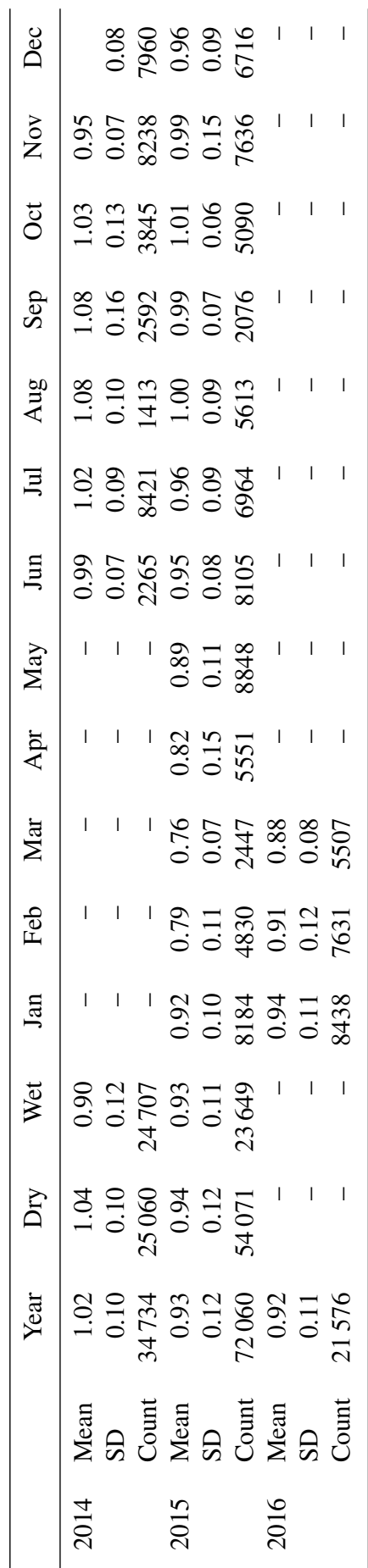

of long-term background GEM concentrations for the SH as reported by Slemr et al. (2015). Mean GEM concentrations reported by Slemr et al. (2015) over 2012-2013 at Cape Grim, Tasmania $\left(40.6832^{\circ} \mathrm{S}, 144.6899^{\circ} \mathrm{E}\right)$, and by Morrison et al. (2015) over 2014-2015 at Singleton, NSW $\left(32.4777^{\circ} \mathrm{S}\right.$, $151.1018^{\circ} \mathrm{E}$ ), were both $0.86 \mathrm{ng} \mathrm{m}^{-3}$ (9\% lower), suggesting a slight latitudinal gradient in GEM across the Australian continent. These differences are statistically significant (Student's $t$ test, $p<0.0001$ ), though differences in the sampling periods introduces additional uncertainty due to seasonal variation at the sites. Further, an analysis of systematic instrument uncertainty for the Tekran 2537 by Slemr et al. (2015) showed this to be $\sim 10 \%$. A latitudinal gradient within the SH was more generally seen in median annual GEM concentrations for GMOS sites in 2013-2014, based on data from five sites (Sprovieri et al., 2016). GEM measurements at ATARS were coincident with those reported by Sprovieri et al. (2016) for only the latter 6 months of 2014, a period spanning the late dry season and early wet season. Concentrations during this period were $1.02 \pm 0.10 \mathrm{ng} \mathrm{m}^{-3}$ higher than the overall mean at ATARS, though still lower than mean values reported for other tropical GMOS sites.

A seasonal trend is apparent in the GEM time series (Fig. 2), which shows higher concentrations during the dry season compared to the wet. Wind sector analysis also shows distinctly different wind patterns between wet and dry seasons (Fig. 3). During the wet season, $\sim 60 \%$ of winds come to the site from a westerly direction, consistent with shifting of the ITCZ and associated low-pressure systems towards northern Australia. In the dry season, southeasterly to northeasterly winds are more common $(\sim 65 \%$ between 30 and $\left.150^{\circ}\right)$, although there is also a notable westerly element. Concentration distributions vary between seasons, with a larger fraction of values above $1 \mathrm{ng} \mathrm{m}^{-3}$ seen in the dry period. Within each season, however, these distributions do not change significantly with wind direction. Furthermore, the small percentage of winds arriving from the southwest show no change in GEM distribution, implying that the low mercury emissions from Darwin are not significantly impacting measurements and that overall trends are indicative of influences from the global atmospheric mercury pool rather than local sources.

Figure 2 shows that the highest GEM values are concentrated into short peaks, clustered more heavily around the mid- to late dry season. In the absence of local anthropogenic sources, this is considered consistent with biomassburning events and the associated release of mercury from volatilisation and thermal desorption from vegetation and soils (Melendez-Perez et al., 2014). These biomass-burning events occur extensively in northern Australia throughout the dry season as the result of natural and accidental lighting, as well as part of local land management practices (RusselSmith et al., 2007). Nelson et al. (2009) concluded that burning in the northernmost part of Australia can contribute up 

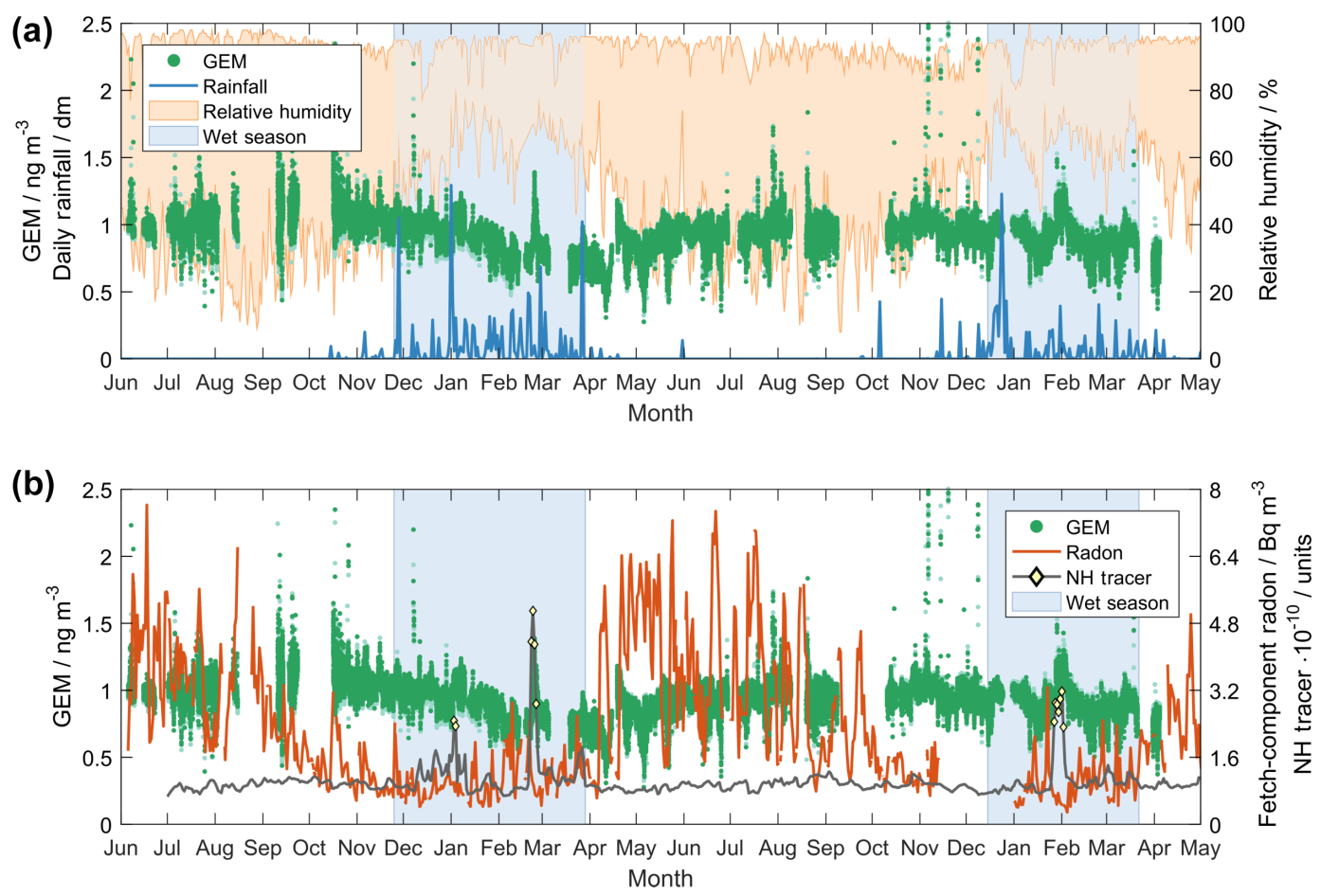

Figure 2. (a) $5 \mathrm{~min}$ GEM data, daily rainfall, and daily $\min / \mathrm{max}$ relative humidity values plus wet-season ranges as defined by Smith et al. (2008). (b) 5 min GEM, hourly fetch-component radon and daily NH tracers. Days defined as NH-influenced are marked with diamonds.

to around $2 \mathrm{~kg} \mathrm{Hg} \mathrm{km}^{-2} \mathrm{a}^{-1}$ to the atmosphere (2006 data, $25 \mathrm{~km} \times 25 \mathrm{~km}$ grid resolution).

An intensive study of these biomass-burning events undertaken at ATARS during the early dry season in 2014 also confirmed spikes in GEM concentration that were associated with biomass burning (Mallet et al., 2016; Desservettaz et al., 2017). The distance to the fire and atmospheric dispersion, as well as vegetation type and associated mercury loading, were all identified as factors influencing the strength of these biomass-burning signals. Desservettaz et al. (2017) calculated emission factors for GEM between 0.0035 and $0.032 \mathrm{~g} \mathrm{Hg}$ per $\mathrm{kg}$ dry fuel, around 2 orders of magnitude higher than that reported by Andreae and Merlet (2001, and references within) for savannah grasslands. The fires observed by Desservettaz et al. (2017) were shown to be from scrubland fires rather than grassland fires, excluding the possibility of direct comparison between the two results. With a full suite of greenhouse gas and aerosol measurements taking place at ATARS, further identification of smoke plumes and precise calculation of emission factors is possible in a manner that is comparable with previous studies.

Wet-season GEM concentrations in 2014-2015 were characterised by a steady, gradual decrease that reversed abruptly in early April shortly after the onset of the dry season (Fig. 2). GEM concentrations during the 2015-2016 wet season saw a similar, though much less distinct decrease over a shorter and drier season. Figure 2 also shows that fetch-component radon concentrations begin to drop in both years around September-October, which HYSPLIT trajectories show is coincident with air mass origin shifting away from the Australian continent and towards the northern Arafura and Timor seas. Throughout the wet season fetch-component radon remains low, though not at baseline levels (Zahorowski et al., 2013; Chambers et al., 2016b), implying that there is still some terrestrial influence on incoming air masses from the Australian continent or surrounding islands to the north. Wetseason wind data (Fig. 3) confirm that the predominant fetch during this period is from the west, where the Timor Sea lies less than $2 \mathrm{~km}$ from ATARS. Air-sea exchange of mercury is complex, with the ocean generally considered a net sink for atmospheric mercury (Mason and Sheu, 2002; Song et al., 2015). Reduction of mercury within the photolytic zone can give rise to increased concentrations of elemental mercury and hence evasion of GEM to the atmosphere (Soerensen et al., 2014). Terrestrial surfaces are also commonly sources of GEM; Nelson et al. (2012) modelled terrestrial mercury emission fluxes over Australia that were generally between 8 and $44 \mu \mathrm{g} \mathrm{m}^{-2} \mathrm{a}^{-1}$ from soil and vegetation. Figure 3 does not show a strong difference in concentration distributions between the two source regions.

The increase in GEM concentrations in the early 2015 dry season was coincident with a shift to largely terrestrialinfluenced fetch, as evidenced by a coincident increase in fetch-component radon, as well as with the conclusion of 


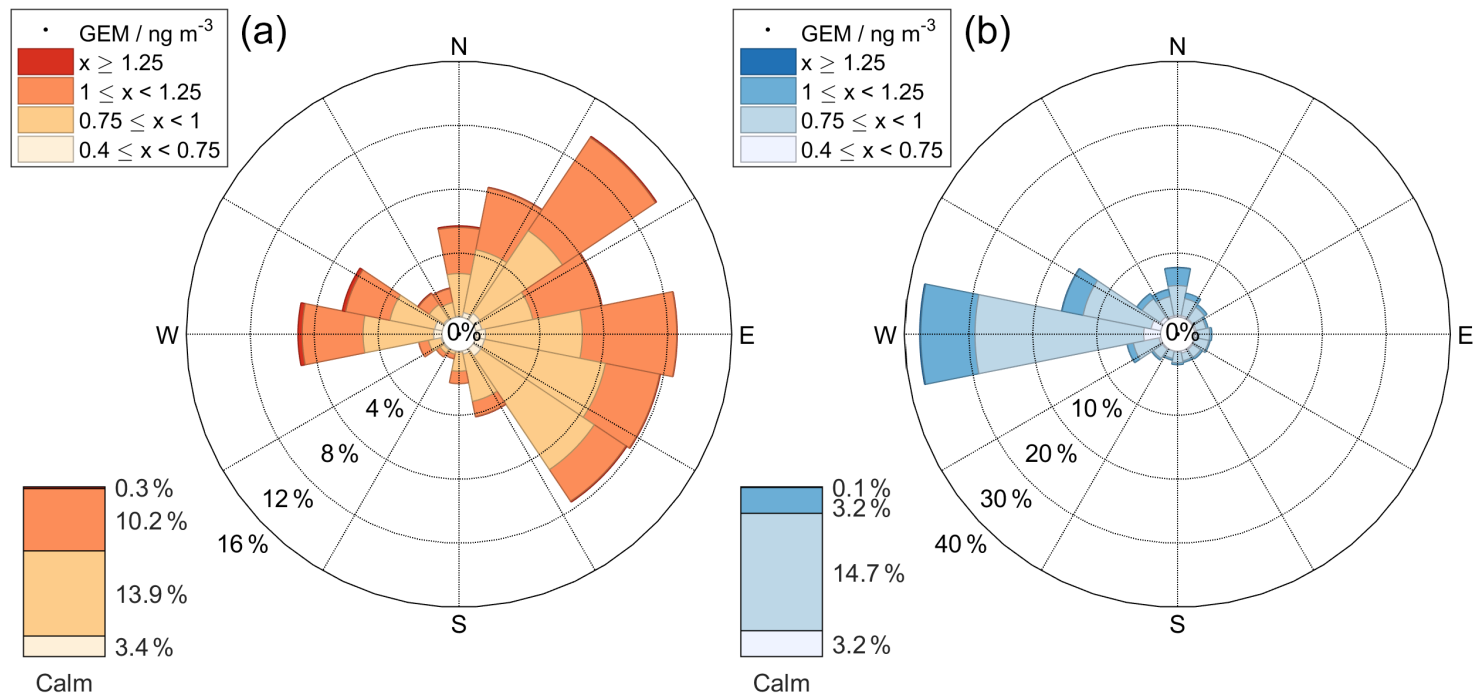

Figure 3. Directional GEM concentration distributions for (a) dry season and (b) all wet-season half-hourly GEM data.

the monsoon season. The timing offset between decreases in GEM and fetch-component radon in the early wet and late dry seasons suggests that air mass origin is not the only influence on wet-season GEM decreases. Within tropical regions, wet deposition has been shown to be a significant pathway for mercury from the atmosphere to both oceanic and terrestrial ecosystems, even in relatively low-mercury air and despite the low solubility of mercury in its elemental form (Fostier et al., 2000; Costa et al., 2012; Hansen and Gay, 2013; Soerensen et al., 2014; Shanley et al., 2015). Mercury "rainout" - or the tendency for mercury rainwater loading to decrease with increasing precipitation - has also been demonstrated in Mercury Deposition Network (MDN) data in North America (Glass and Sorensen, 1999; Prestbo and Gay, 2009) and positive correlations between GEM (TGM) and rainwater mercury have been reported in MDN data (GEM; Cole et al., 2014) and at Cape Point, South Africa (TGM; Brunke et al., 2016). Re-emission of any deposited mercury is likely to be inhibited throughout the wet season, as it has been shown that GEM emission from background mercury soils is suppressed when the soils are saturated (Briggs and Gustin, 2013). Mercury wet deposition is currently not being measured at ATARS; however, given the large differences in GEM trends between the wet and dry seasons, these measurements could help to highlight differing processes between these periods.

\subsection{Diurnal variation}

Short, significant troughs in GEM values can be seen in Fig. 2, down to a minimum value of $0.28 \mathrm{ng} \mathrm{m}^{-3}$. These are more pronounced in the dry season, though still common during the wet. GEM recoveries from standard additions during these periods were investigated and remained within $10 \%$ of expected values with no evident pattern throughout the day, implying the drops in observed GEM were due to natural phenomena and not a change in instrument GEM recovery. Atmospheric mercury depletion events (AMDEs) and the mechanisms behind them have been well documented in polar regions (Steffen et al., 2008), though other similar events have been observed within the mid-latitudes (Mao et al., 2008; Brunke et al., 2010; Engle et al., 2010; Moore et al., 2013; Morrison et al., 2015; Fu et al., 2016; Howard and Edwards, 2017). The mechanisms behind these mid-latitude depletion events are less clear and likely varied - with hypotheses such as chemical conversion of GEM to RM and subsequent deposition, transport of GEM-depleted air masses, or deposition of GEM from isolated atmospheric pools being offered. Closer inspection of the dips in GEM observed at ATARS reveals that they occur overnight and are particularly pronounced in the early hours of the morning, with a marked rebound following sunrise.

The pattern of overnight GEM depletion is shown in diurnal composite data in Fig. 4, along with diurnal-component radon and wind direction. Days have been defined from midday to midday, then sorted into groups according to quartiles of the diurnal-component radon value at sunrise (marked in the top figures). As radon fluxes are, across daily timescales, constant to first-order approximation, nocturnal build-up of radon is indicative of atmospheric stability, with highest radon values indicating the most stable atmospheres. This follows the radon-based stability categorisation method described by Chambers et al. (2016a) and Williams et al. (2016). In the dry season (left), it can clearly be seen that the magnitude of nocturnal GEM depletion increases with increasing stability and, conversely, little to no depletion occurs under well-mixed boundary layers. Wind directions for the well-mixed category shift from coastal (westerly) in the 
(a)

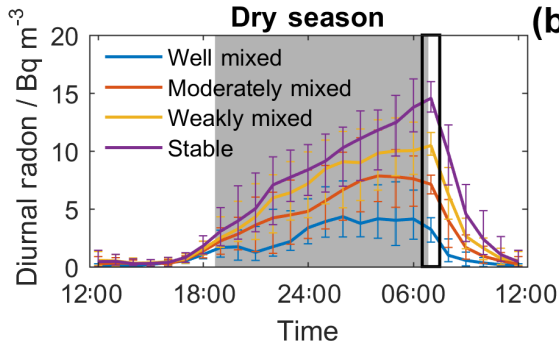

(c)

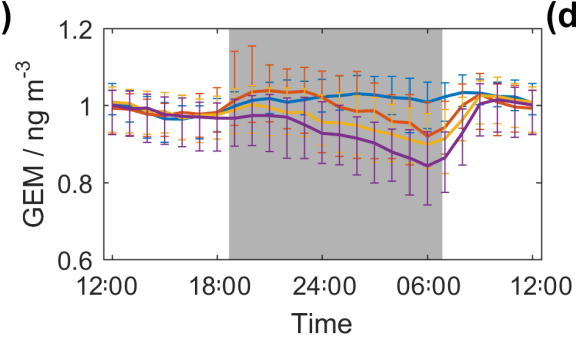

(e)

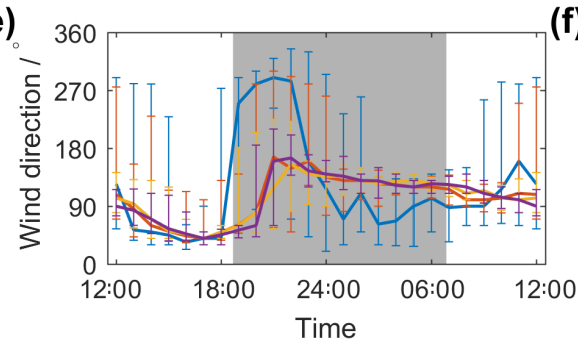

(b)

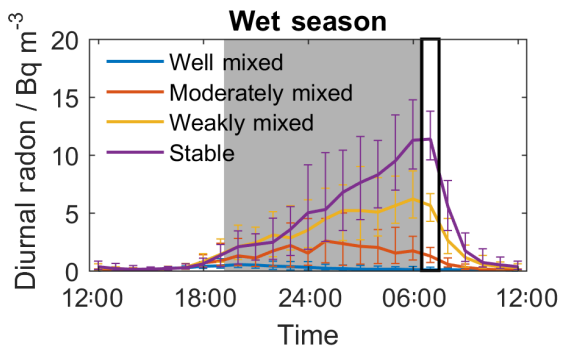

(d)

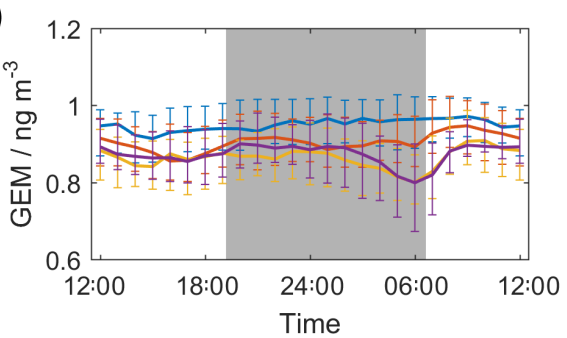

(f)

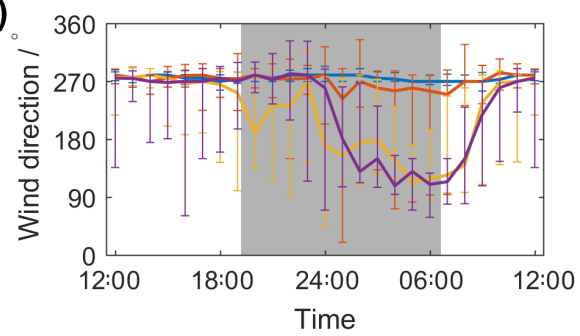

Figure 4. Diurnal composites of hourly radon (a, b), GEM (c, d), and wind direction (e, f) for (left) dry-season data and (right) all wetseason data. Edges of shading denote median sunset/sunrise times for each season. Data have been split into stability categories based on diurnal-component radon quartiles at sunrise (marked in top panels). Lines are median values, and error bars indicate inter-quartile ranges.

early evening to terrestrial during the night. In contrast, wind directions for moderately mixed to stable boundary layer categories are very similar to each other, shifting from a northeasterly to southeasterly direction shortly after sunset. Terrestrial fetches encompass this range of directions and the abrupt shift in wind direction at around 20:00 has little impact on the rates of GEM depletion or radon accumulation under these stability categories. This shows that changes in advection of GEM from local source/sink regions are not responsible for observed depletion.

Wet-season diurnal-component radon values (right) are lower than in the dry season, which fits with wind profile and fetch-component radon data showing greater influence of oceanic fetch. Additionally, during the wet season rates of radon emission may be reduced in saturated soils, as reduction of pore space inhibits upward mobility to the point where radon within the soil will undergo radioactive decay before reaching the surface (Griffiths et al., 2010). During the wet season, well-mixed and moderately mixed categories are more indicative of the influence of ocean fetch than stability, as evidenced by wind directions of $273 \pm 8^{\circ}$ for these two categories. For weakly mixed and stable categories, wind direction shifts southerly and easterly throughout the evening, from an oceanic fetch to a terrestrial fetch. It is not until this shift in wind direction occurs that GEM depletion is observed, at a similar rate to that seen in the dry season under moderately mixed to stable categories.

We suggest from these observations during the wet and dry seasons that the observed depletion results from deposition of GEM over terrestrial surfaces. Under increasingly lower capping inversions associated with more stable boundary layers, a near-constant rate of surface deposition would result in greater concentration drops within the boundary layer, consistent with the observations at ATARS. Turbulent break-up of the nocturnal boundary layer at sunrise is also consistent with the rebound of GEM concentrations and drop in diurnal-component radon observed at this time. The rebound of GEM, however, begins the hour before diurnal-component radon signals the break-up of the nocturnal boundary layer. In the absence of changes to advection or entrainment, this suggests emission of GEM from the surface. Furthermore, for stability categories where GEM depletion has taken place, daytime GEM concentration peaks at around 10:00 before decreasing to a minimum at around 15:00, where low radon values indicate the strongest turbulent mixing with free-tropospheric air. This "overshoot" of GEM in the early morning also cannot be explained by entrainment and, at least in the dry season, by changes to fetch. 


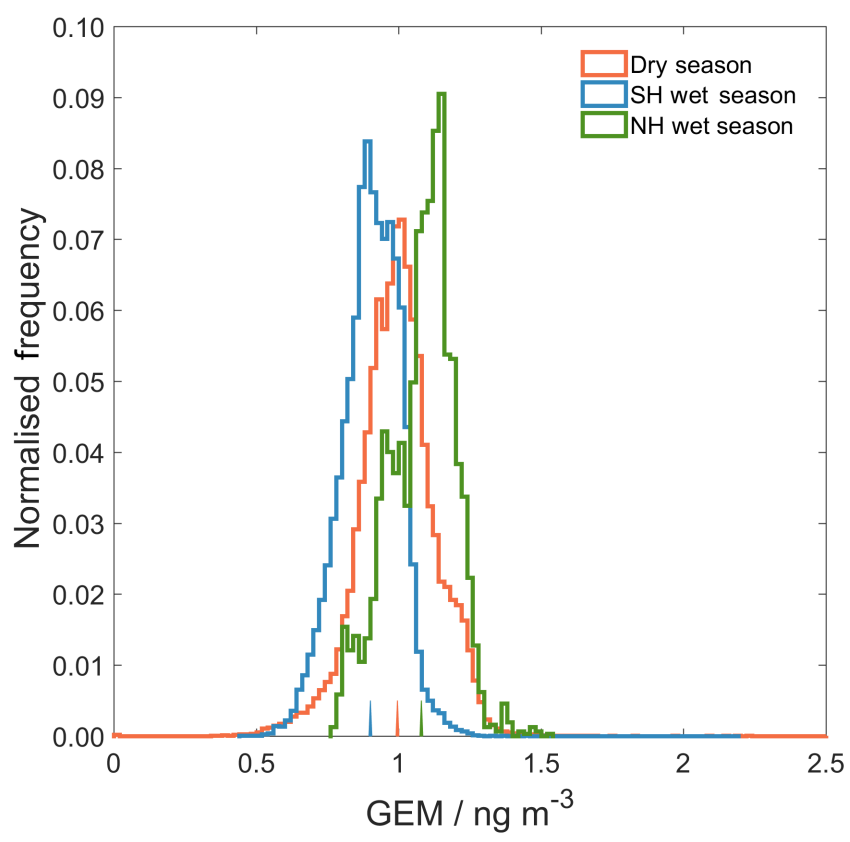

Figure 5. Normalised frequency for all $5 \mathrm{~min}$ GEM data, split into dry season, $\mathrm{SH}$ wet season, and $\mathrm{NH}$ wet season. Vertical lines at bottom of figure indicate mean values.

Early-morning GEM emission would likely be from the most readily volatile surface mercury, released under low-light conditions (shading denotes the period between geometric sunset/sunrise and so astronomical twilight will begin up to 75 min prior to the shaded edge). We propose that this initial release of GEM is volatilised from the reduction of mercury deposited overnight, as it has been shown that the most recently deposited mercury during AMDEs is preferentially released due to photochemical reactions (Sherman et al., 2010).

Previous studies have shown that surface GEM fluxes over soils with mercury concentration at background levels are generally bidirectional, with little controlling influence from soil mercury concentration (Agnan et al., 2016, and references within). Correlations with solar radiation and air temperature tend to lead to emission fluxes throughout the day and deposition or near-zero flux overnight. Howard and Edwards (2017), whilst undertaking micrometeorological measurements of surface GEM fluxes over a background mercury substrate grassland, observed nocturnal atmospheric mercury depletion events (NAMDEs) similar to the ones seen at ATARS. They attributed these events to enhanced nocturnal deposition of GEM under shallow, stable boundary layers. Enhancements in morning GEM emission were seen in days following the depletion events, similarly providing evidence for volatilisation of recently deposited mercury. Further, cumulative GEM exchange over the 20-day study was near zero, highlighting the short-lived nature of this nocturnal GEM sink. This result, and the radon-based analyses pre- sented earlier, provides strong evidence for a "multi-hop" process of atmospheric transport.

NAMDEs have also been observed in the $\mathrm{NH}$, in a range of ecosystems ranging from coastal to forested (Mao et al., 2008; Engle et al., 2010; Fu et al., 2016). Mao et al. (2008) attributed $70 \%$ of their observed depletion to surface deposition and $\mathrm{Fu}$ et al. (2016) provided modelling evidence showing that stable boundary layers of height $100 \mathrm{~m}$ can be completely depleted of GEM due to deposition processes. The pervasiveness of NAMDEs across multiple ecosystems, and their pervasiveness throughout the ATARS time series across all seasons, suggests that this multi-hop process is widespread. It is important to note that, due to inhibited mixing at the top of the nocturnal boundary layer, the extent of any nocturnal depletion is limited to within tens to hundreds of metres above the surface. Beyond this, movement of free-tropospheric air continues to enable long-range transport of GEM. Nevertheless, extensive and rapid bidirectional exchange with the surface would have a significant impact on our understanding of atmospheric mercury transport, impacting the relative importance of intermediate and regional-scale sources, as well as expected timescales for observed decreases in environmental mercury following actions proposed under the Minamata Convention (Lindberg et al., 2007).

\subsubsection{Long-range transport}

With seasonal changes in the latitudinal position of the ITCZ, ATARS is periodically located north of the atmospheric equator (Hamilton et al., 2008) and so the possibility of interhemispheric transport to the site was also of interest. Figure 2 shows the GEOS-Chem output for NH-released tracer concentrations at ATARS. Throughout most of the year - and consistently through the dry season - this value remains low, indicating that the site is far enough below the atmospheric equator to not be affected by transport of $\mathrm{NH}$ air. However, there are notable periods when this tracer value increases, along with coincident GEM increases. We arbitrarily defined air masses at the site to be significantly influenced by $\mathrm{NH}$ air (herein termed "NH wet season") when the ratio of $\mathrm{NH}$ tracers to SH tracers was greater than 0.5 (ratio not shown). Under this definition, ATARS saw $13 \mathrm{NH}$-influenced days over three distinct periods, all during the wet season and indicated in the lower panel of Fig. 2. Hereafter, wet-season data that exclude these periods of $\mathrm{NH}$ influence are termed "SH wet season".

The normalised frequency distribution of $\mathrm{NH}$ wet-season GEM data is compared against those of dry season and SH wet-season data in Fig. 5. Mean values for each were $1.08 \pm 0.12 \mathrm{ng} \mathrm{m}^{-3} \quad(n=3048), \quad 0.97 \pm 0.13 \mathrm{ng} \mathrm{m}^{-3} \quad(n=$ $81073)$, and $0.90 \pm 0.10 \mathrm{ng} \mathrm{m}^{-3}(n=46191)$, respectively. The differences between these means were small but significant; Student's $t$ tests showed the minimum differences between the $95 \%$ confidence interval of each mean to be 

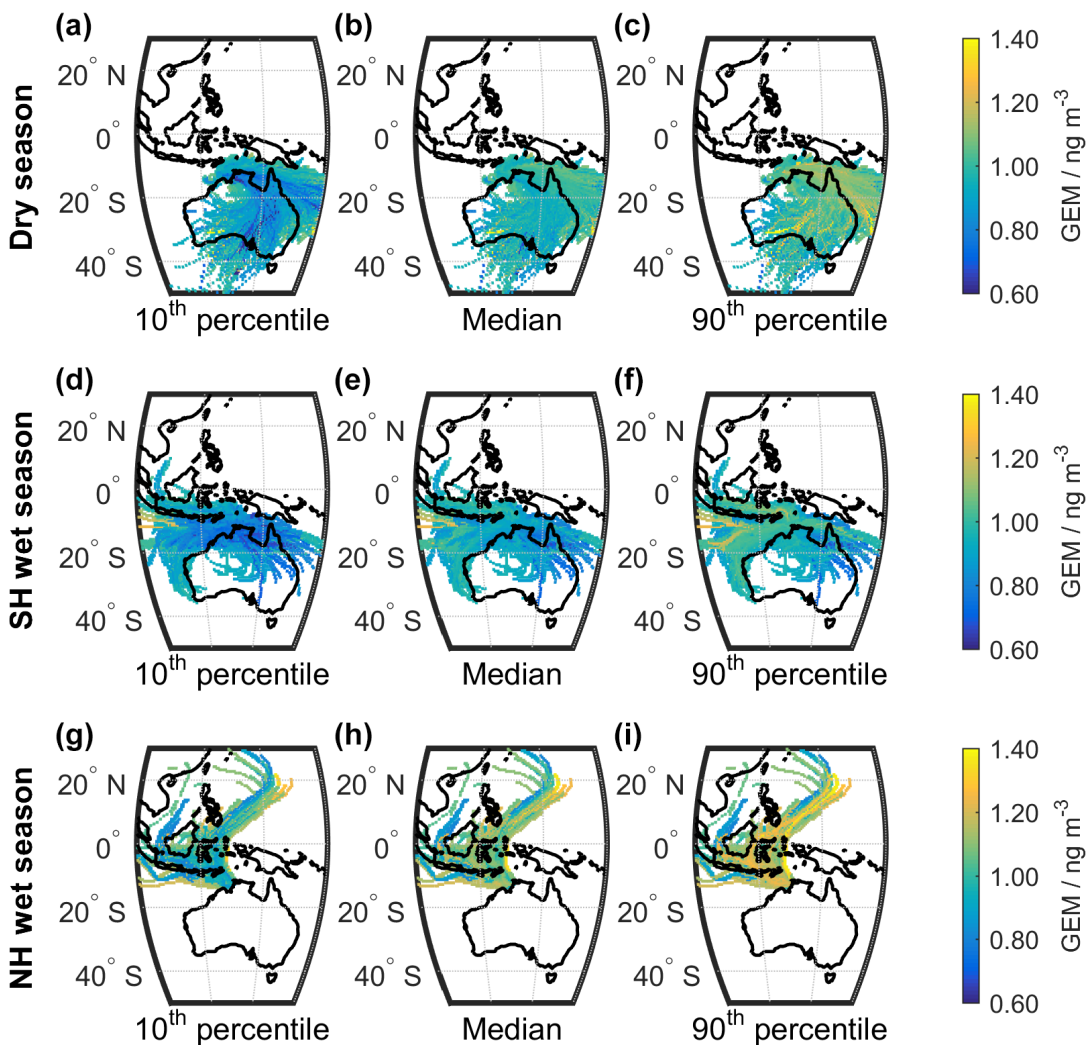

Figure 6. 10th percentile (left), median (centre), and 90th percentile (right) of hourly GEM-weighted HYSPLIT trajectories for $0.5^{\circ} \times 0.5^{\circ}$ grid squares. Panels (a)-(c) are for dry-season data, (d)-(f) for SH wet-season data, and (g)-(i) for NH wet-season data. NH wet-season map created using 10-day back trajectories, all others using 5-day trajectories.

$0.10 \mathrm{ng} \mathrm{m}^{-3}$ (NH wet - dry) and $0.07 \mathrm{ng} \mathrm{m}^{-3}$ (dry - SH wet). Comparison with log-normal probability density functions for other GMOS sites over the years 2013-2014 (Fig. 4; Sprovieri et al., 2016) shows that GEM data sampled at ATARS are more closely related to those from other SH sites, rather than tropical or NH sites. This is likely due to the location of ATARS within the Maritime Continent - a region of high variability in the latitudinal position of the ITCZ and its southerly latitude that places it outside this range and hence within the atmospheric SH for most of the year.

Air mass source transport to ATARS across seasons was further investigated using 5-day HYSPLIT back trajectories. For NH-influenced air masses, use of 5-day trajectories and the geographic equator was found to be a poor predictor of $\mathrm{NH}$ influence at this site, with only $1.2 \%$ of these trajectories originating from within the geographical NH. This is likely due to the significant disconnect between the geographical and meteorological equators over the Maritime Continent during the wet season. As such, 10-day back trajectories were calculated for these periods. Figure 6 shows median, 10th, and 90th percentile GEM-weighted trajectory coordinates for $0.5^{\circ} \times 0.5^{\circ}$ grid cells. During the dry season (top row), the influence of persistent high-pressure cells across the Australian continent can be seen, with most air parcels flowing over central and northeastern Australia. Changes to air mass source regions are seen with the southward movement of the ITCZ and associated low-pressure cells that characterise the $\mathrm{SH}$ wet season (centre row). The differing GEM concentration distributions between the two seasons outlined earlier are further apparent in these two figures. For $\mathrm{NH}-$ influenced air masses (bottom row), this analysis shows that most air masses - particularly those with the highest GEM concentrations - passed over the Indonesian archipelago. North of this, air masses moved over the South China Sea or western Pacific Ocean, with little influence from terrestrial South East Asia. Given that Indonesia's population is greater than 250 million and its biomass-burning season coincides with the Australian monsoon, it is likely that the observed increases in GEM concentrations in $\mathrm{NH}$-influenced air masses are more indicative of anthropogenic or biomass GEM source influence from the Indonesian archipelago than the NH background source pool. Further investigation using chemical transport and mercury emission modelling is needed. Regardless, the current analysis shows that ATARS does observe air masses of $\mathrm{NH}$ origin and that measurements of GEM and other atmospheric species during these periods may help to assess the effectiveness of transport models in- 
vestigating hemispheric air exchange associated with movement of the atmospheric equator.

\section{Conclusions}

We present here the first 2 years of ongoing measurements of GEM taken in tropical Australia. Comparison with other Australian datasets suggests that a latitudinal gradient of GEM exists across the continent, with higher values towards the equator. Air masses from the NH were shown to intermittently impact the tropical site ATARS, with associated increases in GEM. Generally, the concentrations seen at ATARS were indicative of SH rather than tropical air, as determined by comparison with other GMOS monitoring stations around the globe.

Seasonal variation in GEM was observed, with higher values observed in the tropical dry season compared to the wet. Spikes in GEM associated with biomass burning in the region were measured, taking place during the mid- to late dry season. Wet-season GEM showed a decreasing trend throughout 2014-2015; this was apparent though not as pronounced in the drier 2015-2016 season. The cessation of this downward trend coincides with shifts of air mass source regions from oceanic to terrestrial; however, the reverse is not the case for the onset of this trend. It is likely that precipitation rainout or aqueous-phase oxidation of GEM is responsible for this observed downward trend. Continued monitoring and wet deposition data may help to explain these seasonal features.

Daily cycles in GEM were observed at the site, characterised by nocturnal decreases in concentration followed by rapid increases around sunrise, then further decreases throughout the day. Differences in these daily trends between wet and dry seasons, along with associated changes in wind direction and stability, suggest that these nocturnal atmospheric mercury depletion events are related to dry deposition of GEM over terrestrial surfaces under increasingly stable boundary layers. Analyses using diurnal-component radon suggest the rapid increases around sunrise are partly due to volatilisation of newly deposited mercury, such as seen in other NAMDEs and in Arctic AMDEs. The extent of this multi-hop phenomenon may be widespread, which would have a significant impact on our understanding of atmospheric mercury transport, the delivery of atmospheric mercury to the environment, and the legacy of anthropogenic emissions of mercury.

Currently, multi-annual atmospheric mercury datasets for tropical and $\mathrm{SH}$ sites are rare, impacting the skill of regional and global models designed to further our understanding of the natural mercury cycle and its potential impacts on human and environmental health. The value of measurements such as these is in comparisons with other similar measurements around the globe. As such, the addition of this site to monitoring networks such as the Global Mercury Observation System (GMOS) or the Asia Pacific Mercury Moni- toring Network (APMMN) is important in achieving greater understanding of the mercury cycle, as it is currently only one of two monitoring sites located in the tropical Eastern Hemisphere.

Article 19 of the Minamata Convention commits parties to develop and improve anthropogenic mercury inventories; efforts to monitor mercury and mercury compounds in environmental media; and modelling of mercury transport (including long-range transport and deposition), transformation and fate in a range of ecosystems. ATARS is uniquely positioned to enhance the information required for these monitoring and modelling activities.

Data availability. GEM data used for this publication are available from the GMOS data repository (http://gmos.eu/sdi/). Weather data are collected and supplied by the Australian Bureau of Meteorology (http://www.bom.gov.au/climate/data-services/).

Competing interests. The authors declare that they have no conflict of interest.

Acknowledgements. The authors would like to thank Mark Cohen for his assistance with HYSPLIT modelling and Chris Holmes for supplying code and assistance for GEOS-Chem tracer modelling. This research was undertaken with the assistance of resources provided at the NCI National Facility systems at the Australian National University through the National Computational Merit Allocation Scheme supported by the Australian Government.

Edited by: Aurélien Dommergue

Reviewed by: two anonymous referees

\section{References}

Agnan, Y., Dantec, T. L., Moore, C. W., Edwards, G. C., and Obrist, D.: New constraints on terrestrial surface-atmosphere fluxes of gaseous elemental mercury using a global database, Environ. Sci. Technol., 50, 507-524, https://doi.org/10.1021/acs.est.5b04013, 2016.

Andreae, M. and Merlet, P.: Emission of trace gases and aerosols from biomass burning, Global Biogeochem. Cy., 15, 955-966, https://doi.org/10.1029/2000GB001382, 2001.

Angot, H., Barret, M., Magand, O., Ramonet, M., and Dommergue, A.: A 2-year record of atmospheric mercury species at a background Southern Hemisphere station on Amsterdam Island, Atmo. Chem. Phys., 14, 11461-11473, https://doi.org/10.5194/acp-14-11461-2014, 2014.

Angot, H., Dion, I., Vogel, N., Legrand, M., Magand, O., and Dommergue, A.: Multi-year record of atmospheric mercury at Dumont d'Urville, East Antarctic coast: continental outflow and oceanic influences, Atmos. Chem. Phys., 16, 8265-8279, https://doi.org/10.5194/acp-16-8265-2016, 2016.

Arctic Monitoring and Assessment Programme/United Nations Environment Programme (AMAP/UNEP): Technical Background 
Report for the Global Mercury Assessment 2013, Arctic Monitoring and Assessment Programme, 2013.

Australian Bureau of Meteorology (BoM): Climate statistics for Australian locations, http://www.bom.gov.au/climate/averages/ tables/cw_014015.shtml, last access: 29 June 2016.

Australian Bureau of Statistics (ABS): 3218.0 - Regional Population Growth, Australia, 2012-13, http://www.abs.gov.au/ausstats/abs@.nsf/_ (last access: 29 June 2016), 2015.

Australian National Polluntant Inventory (NPI): 2014/2015 data within Australia - All Substances from All Sources, http://www.npi.gov.au/npidata/, last access: 29 June 2016.

Bose-O'Reilly, S., McCarty, K. M., Steckling, N., and Lettmeier, B.: Mercury Exposure and Children's Health, Current Problems in Pediatric and Adolescent Health Care, 40, 186-215, https://doi.org/10.1016/j.cppeds.2010.07.002, 2010.

Bowman, K. P. and Cohen, P. J.: Interhemispheric Exchange by Seasonal Modulation of the Hadley Circulation, J. Atmos. Sci., 54, 2045-2059, https://doi.org/10.1175/15200469(1997)054<2045:IEBSMO>2.0.CO;2, 1997.

Briggs, C. and Gustin, M. S.: Building upon the Conceptual Model for Soil Mercury Flux: Evidence of a Link Between Moisture Evaporation and Hg Evasion, Water Air Soil Pollut., 224, 13 pp., https://doi.org/10.1007/s11270-013-1744-5, 2013.

Brunke, E.-G., Labuschagne, C., Ebinghaus, R., Kock, H. H., and Slemr, F.: Gaseous elemental mercury depletion events observed at Cape Point during 2007-2008, Atmos. Chem. Phys., 10, 11211131, https://doi.org/10.5194/acp-10-1121-2010, 2010.

Brunke, E.-G., Walters, C., Mkololo, T., Martin, L., Labuschagne, C., Silwana, B., Slemr, F., Weigelt, A., Ebinghaus, R., and Somerset, V.: Mercury in the atmosphere and in rainwater at Cape Point, South Africa, Atmos. Environ., 125, 24-32, https://doi.org/10.1016/j.atmosenv.2015.10.059, 2016.

Chambers, S. D., Williams, A., Zahorowski, W., Griffiths, A., and Crawford, J.: Separating remote fetch and local mixing influences on vertical radon measurements in the lower atmosphere, Tellus B, 63, 843-859, https://doi.org/10.1111/j.16000889.2011.00565.x, 2011.

Chambers, S. D., Galeriu, D., Williams, A. G., Melintescu, A., Griffiths, A. D., Crawford, J., Dyer, L., Duma, M., and Zorila, B.: Atmospheric stability effects on potential radiological releases at a nuclear research facility in Romania: Characterising the atmospheric mixing state, J. Environ. Radioactiv., 154, 68-82, https://doi.org/10.1016/j.jenvrad.2016.01.010, 2016a.

Chambers, S. D., Williams, A. G., Conen, F., Griffiths, A. D., Reimann, S., Steinbacher, M., Krummel, P. B., Steele, L., van der Schoot, M., Galbally, I. E., Molloy, S. B., and Barnes, J. E.: Towards a Universal "Baseline" Characterisation of Air Masses for High- and Low-Altitude Observing Stations Using Radon-222, Aerosol Air Qual. Res., 16, 885-899, https://doi.org/10.4209/aaqr.2015.06.0391, 2016b.

Cole, A. S., Steffen, A., Eckley, C. S., Narayan, J., Pilote, M., Tordon, R., Graydon, J. A., St. Louis, V. L., Xu, X., and Branfireun, B. A.: A survey of mercury in air and precipitation across Canada: patterns and trends, Atmosphere, 5, 635-668, https://doi.org/10.3390/atmos5030635, 2014.

Costa, M. F., Landing, W. M., Kehrig, H. A., Barletta, M., Holmes, C. D., Barrocas, P. R., Evers, D. C., Buck, D. G., Vasconcellos, A., Hacon, S. S., Moreira, J. C., and Malm, O.: Mercury in tropi- cal and subtropical coastal environments, Environ. Res., 119, 88100, https://doi.org/10.1016/j.envres.2012.07.008, 2012.

Desservettaz, M., Paton-Walsh, C., Griffith, D. W., Kettlewell, G., Keywood, M. D., van der Schoot, M. V., Ward, J., Mallet, M. D., Milic, A., Miljevic, B., Ristovski, Z. D., Howard, D., Edwards, G. C., and Atkinson, B.: Emission factors of trace gases and particles from tropical savanna fires in Australia, J. Geophys. Res.-Atmos., 122, 6059-6074, https://doi.org/10.1002/2016JD025925, 2017.

Draxler, R. R.: HYSPLIT4 user's guide, Tech. Rep. ERL ARL-230, NOAA Air Resources Laboratory, Silver Spring, MD, 1999.

Draxler, R. R. and Hess, G.: Description of the HYSPLIT_4 modeling system, Tech. Rep. ERL ARL-224, NOAA Air Resources Laboratory, Silver Spring, MD, 1998.

Ebinghaus, R., Jennings, S., Schroeder, W., Berg, T., Donaghy, T., Guentzel, J., Kenny, C., Kock, H., Kvietkus, K., Landing, W., Mühleck, T., Munthe, J., Prestbo, E., Schneeberger, D., Slemr, F., Sommar, J., Urba, A., Wallschläger, D., and Xiao, Z.: International field intercomparison measurements of atmospheric mercury species at Mace Head, Ireland, Atmos. Environ., 33, 30633073, https://doi.org/10.1016/S1352-2310(98)00119-8, 1999.

Edwards, G. C. and Howard, D.: Air-surface exchange measurements of gaseous elemental mercury over naturally enriched and background terrestrial landscapes in Australia, Atmos. Chem. Phys., 13, 5325-5336, https://doi.org/10.5194/acp13-5325-2013, 2013.

Engle, M. A., Tate, M. T., Krabbenhoft, D. P., Schauer, J. J., Kolker, A., Shanley, J. B., and Bothner, M. H.: Comparison of atmospheric mercury speciation and deposition at nine sites across central and eastern North America, J. Geophys. Res.-Atmos., 115, 13 pp., https://doi.org/10.1029/2010JD014064, 2010.

Fostier, A.-H., Forti, M., Guimarães, J., Melfi, A., Boulet, R., Espirito Santo, C., and Krug, F.: Mercury fluxes in a natural forested Amazonian catchment (Serra do Navio, Amapá State, Brazil), Sci. Total Environ., 260, 201-211, https://doi.org/10.1016/S0048-9697(00)00564-7, 2000.

Fu, X., Zhu, W., Zhang, H., Sommar, J., Yu, B., Yang, X., Wang, X., Lin, C.-J., and Feng, X.: Depletion of atmospheric gaseous elemental mercury by plant uptake at Mt. Changbai, Northeast China, Atmos. Chem. Phys., 16, 12861-12873, https://doi.org/10.5194/acp-16-12861-2016, 2016.

Glass, G. E. and Sorensen, J. A.: Six-year trend (1990-1995) of wet mercury deposition in the Upper Midwest, USA, Environ. Sci. Technol., 33, 3303-3312, https://doi.org/10.1021/es9806736, 1999.

Griffiths, A., Zahorowski, W., Element, A., and Werczynski, S.: A map of radon flux at the Australian land surface, Atmos. Chem. Phys., 10, 8969-8982, https://doi.org/10.5194/acp-108969-2010, 2010.

Griffiths, A. D., Chambers, S. D., Williams, A. G., and Werczynski, S.: Increasing the accuracy and temporal resolution of two-filter radon-222 measurements by correcting for the instrument response, Atmos. Meas. Tech., 9, 2689-2707, https://doi.org/10.5194/amt-9-2689-2016, 2016.

Gustin, M. S., Engle, M., Ericksen, J., Lyman, S., Stamenkovic, J., and Xin, M.: Mercury exchange between the atmosphere and low mercury containing substrates, Appl. Geochem., 21, 1913-1923, https://doi.org/10.1016/j.apgeochem.2006.08.007, 2006. 
Gustin, M. S., Huang, J., Miller, M. B., Peterson, C., Jaffe, D. A., Ambrose, J., Finley, B. D., Lyman, S. N., Call, K., Talbot, R., Feddersen, D., Mao, H., and Lindberg, S. E.: Do we understand what the mercury speciation instruments are actually measuring? Results of RAMIX, Environ. Sci. Technol., 47, 7295-7306, https://doi.org/10.1021/es3039104, 2013.

Hamilton, J. F., Allen, G., Watson, N. M., Lee, J. D., Saxton, J. E., Lewis, A. C., Vaughan, G., Bower, K. N., Flynn, M. J., Crosier, J., Carver, G. D., Harris, N. R., Parker, R. J., Remedios, J. J., and Richards, N. A.: Observations of an atmospheric chemical equator and its implications for the tropical warm pool region, J. Geophys. Res.-Atmos., 113, 12 pp., https://doi.org/10.1029/2008JD009940, 2008.

Hansen, A. and Gay, D.: Observations of mercury wet deposition in Mexico, Environ. Sci. Pollut. Res., 20, 8316-8325, https://doi.org/10.1007/s11356-013-2012-3, 2013.

Holmes, C., Jacob, D., Corbitt, E., Mao, J., Yang, X., Talbot, R., and Slemr, F.: Global atmospheric model for mercury including oxidation by bromine atoms, Atmos. Chem. Phys., 10, 12037 12057, https://doi.org/10.5194/acp-10-12037-2010, 2010.

Holmes, C. D. and Prather, M. J.: An atmospheric definition of the equator and its implications for atmospheric chemistry and climate, Nat. Geosci., in press, 2017.

Holmes, C. D., Jacob, D. J., and Yang, X.: Global lifetime of elemental mercury against oxidation by atomic bromine in the free troposphere, Geophys. Res. Lett., 33, 5 pp., https://doi.org/10.1029/2006GL027176, 2006.

Horowitz, H. M., Jacob, D. J., Zhang, Y., Dibble, T. S., Slemr, F., Amos, H. M., Schmidt, J. A., Corbitt, E. S., Marais, E. A., and Sunderland, E. M.: A new mechanism for atmospheric mercury redox chemistry: implications for the global mercury budget, Atmos. Chem. Phys., 17, 6353-6371, https://doi.org/10.5194/acp17-6353-2017, 2017.

Howard, D. and Edwards, G. C.: Mercury fluxes over an Australian alpine grassland and observation of nocturnal atmospheric mercury depletion events, Atmos. Chem. Phys. Discuss., https://doi.org/10.5194/acp-2017-580, in review, 2017.

Lindberg, S., Bullock, R., Ebinghaus, R., Engstrom, D., Fenh, X., Fitzgerald, W., Pirrone, N., Prestbo, E., and Seigneur, C.: A Synthesis of Progress and Uncertainties in Attributing the Sources of Mercury in Deposition, AMBIO, A Journal of the Human Environment, 36, 19-33, https://doi.org/10.1579/00447447(2007)36[19:ASOPAU]2.0.CO;2, 2007.

Mallet, M. D., Desservettaz, M. J., Miljevic, B., Milic, A., Ristovski, Z. D., Alroe, J., Cravigan, L. T., Jayaratne, E. R., PatonWalsh, C., Griffith, D. W. T., Wilson, S. R., Kettlewell, G., van der Schoot, M. V., Selleck, P., Reisen, F., Lawson, S. J., Ward, J., Harnwell, J., Cheng, M., Gillett, R. W., Molloy, S. B., Howard, D., Nelson, P. F., Morrison, A. L., Edwards, G. C., Williams, A. G., Chambers, S. D., Werczynski, S., Williams, L. R., Winton, H. L., Atkinson, B., Wang, X., and Keywood, M. D.: Biomass burning emissions in north Australia during the early dry season: an overview of the 2014 SAFIRED campaign, Atmos. Chem. Phys. Discuss.,https://doi.org/10.5194/acp-2016-866, in review, 2016.

Mao, H., Talbot, R. W., Sigler, J. M., Sive, B. C., and Hegarty, J. D.: Seasonal and diurnal variations of $\mathrm{Hg}^{\circ}$ over New England, Atmos. Chem. Phys., 8, 1403-1421, https://doi.org/10.5194/acp8-1403-2008, 2008.
Mason, R. and Sheu, G.-R.: Role of the ocean in the global mercury cycle, Global Biogeochem. Cy., 16, 1-14, https://doi.org/10.1029/2001GB001440, 2002.

Mason, R. P., Choi, A. L., Fitzgerald, W. F., Hammerschmidt, C. R., Lamborg, C. H., Soerensen, A. L., and Sunderland, E. M.: Mercury biogeochemical cycling in the ocean and policy implications, Environ. Res., 119, 101-117, https://doi.org/10.1016/j.envres.2012.03.013, 2012.

Melendez-Perez, J. J., Fostier, A. H., Carvalho Jr., J., Windmöller, C. C., Santos, J. C., and Carpi, A.: Soil and biomass mercury emissions during a prescribed fire in the Amazonian rain forest, Atmos. Environ., 96, 415-422, https://doi.org/10.1016/j.atmosenv.2014.06.032, 2014.

Moore, C. W., Obrist, D., and Luria, M.: Atmospheric mercury depletion events at the Dead Sea: Spatial and temporal aspects, Atmos. Environ., 69, 231-239, https://doi.org/10.1016/j.atmosenv.2012.12.020, 2013.

Morrison, A. L., Nelson, P. F., and Howard, D.: Ambient atmospheric mercury in the Hunter Valley, NSW, in: 22nd International Clean Air and Environment Conference, Melbourne, Australia, 20-23 September, 2015.

Müller, D., Wip, D., Warneke, T., Holmes, C., Dastoor, A., and Notholt, J.: Sources of atmospheric mercury in the tropics: continuous observations at a coastal site in Suriname, Atmos. Chem. Phys., 12, 7391-7397, https://doi.org/10.5194/acp-127391-2012, 2012.

Munthe, J., Wänberg, I., Pirrone, N., Iverfeldt, Å., Ferrara, R., Ebinghaus, R., Feng, X., Gårdfeldt, K., Keeler, G., Lanzillotta, E., Lindberg, S., Lu, J., Mamane, Y., Prestbo, E., Schmolke, S., and Schroeder, W.: Intercomparison of methods for sampling and analysis of atmospheric mercury species, Atmos. Environ., 35, 3007-3017, https://doi.org/10.1016/S1352-2310(01)001042, 2001.

Nelson, P. F., Nguyen, H., Morrison, A. L., Malfroy, H., Cope, M. E., Hibberd, M. F., Lee, S., McGregor, J. L., and Meyer, M.: Mercury sources, transportation and fate in Australia, Report, Department of Environment, Water, Heritage \& the Arts, 2009.

Nelson, P. F., Morrison, A. L., Malfroy, H. J., Cope, M., Lee, S., Hibberd, M. L., Meyer, C., and McGregor, J.: Atmospheric mercury emissions in Australia from anthropogenic, natural and recycled sources, Atmos. Environ., 62, 291-302, https://doi.org/10.1016/j.atmosenv.2012.07.067, 2012.

Peel, M., Finlayson, B., and McMahon, T.: Updated world map of the Köppen-Geiger climate classification, Hydrol. Earth Syst. Sci., 11, 1633-1644, https://doi.org/10.5194/hess-11-1633-2007, 2007.

Prestbo, E. M. and Gay, D. A.: Wet deposition of mercury in the US and Canada, 1996-2005: Results and analysis of the NADP mercury deposition network (MDN), Atmos. Environ., 43, 42234233, https://doi.org/10.1016/j.atmosenv.2009.05.028, 2009.

Russel-Smith, J., Yates, C. P., Whitehead, P. J., Smith, R., Craig, R., Allen, G. E., Thackway, R., Frakes, I., Cridland, S., Meyer, M. C., and Malcolm Gill, A.: Bushfires "down under": patterns and implications of contemporary Australian landscape burning, Journal of the International Association of Wildland Fire, 16, 361-377, https://doi.org/10.1071/WF07018, 2007.

Selin, N. E., Jacob, D. J., Park, R. J., Yantosca, R. M., Strode, S., Jaeglé, L., and Jaffe, D.: Chemical cycling 
and deposition of atmospheric mercury: Global constraints from observations, J. Geophys. Res.-Atmos., 112, 14 pp., https://doi.org/10.1029/2006JD007450, 2007.

Shanley, J. B., Engle, M. A., Scholl, M., Krabbenohft, D. P., Brunette, R., Olson, M. L., and Conroy, M. E.: High Mercury Wet Deposition at a "Clean Air" Site in Puerto Rico, Environ. Sci. Technol., 49, 12474-12482, https://doi.org/10.1021/acs.est.5b02430, 2015.

Sherman, L. S., Blum, J. D., Johnson, K. P., Keeler, G. J., Barres, J. A., and Douglas, T. A.: Mass-independent fractionation of mercury isotopes in Arctic snow driven by sunlight, Nat. Geosci., 3, 173-177, https://doi.org/10.1038/NGEO758, 2010.

Sheu, G.-R., Lin, N.-H., Wang, J.-L., Lee, C.-T., Ou Yang, C.-F., and Wang, S.-H.: Temporal distribution and potential sources of atmospheric mercury measured at a high-elevation background station in Taiwan, Atmos. Environ., 44, 2393-2400, https://doi.org/10.1016/j.atmosenv.2010.04.009, 2010.

Slemr, F., Schuster, G., and Seiler, W.: Distribution, speciation, and budget of atmospheric mercury, J. Atmos. Chem., 3, 407-434, https://doi.org/10.1007/BF00053870, 1985.

Slemr, F., Angot, H., Dommergue, A., Magand, O., Barret, M., Weigelt, A., Ebinghaus, R., Brunke, E.-G., Pfaffhuber, K., Edwards, G., Howard, D., Powell, J., Keywood, M., and Wang, F.: Comparison of mercury concentrations measured at several sites in the Southern Hemisphere, Atmos. Chem. Phys., 15, 31253133, https://doi.org/10.5194/acp-15-3125-2015, 2015.

Smith, I., Wilson, L., and Suppiah, R.: Characteristics of the Northern Australian Rainy Season, J. Clim., 21, 4298-4311, https://doi.org/10.1175/2008JCLI2109.1, 2008.

Soerensen, A. L., Jacob, D. J., Streets, D. G., Witt, M. L., Ebinghaus, R., Mason, R. P., Andersson, M., and Sunderland, E. M.: Multi-decadal decline of mercury in the North Atlantic atmosphere explained by changing subsurface seawater concentrations, Geophys. Res. Lett., 39, 6 pp., https://doi.org/10.1029/2012GL053736, 2012.

Soerensen, A. L., Mason, R. P., Balcom, P. H., Jacob, D. J., Zhang, Y., Kuss, J., and Sunderland, E. M.: Elemental Mercury Concentrations and Fluxes in the Tropical Atmosphere and Ocean, Environ. Sci. Technol., 48, 11312-11319, https://doi.org/10.1021/es503109p, 2014.

Song, S., Selin, N., Soerensen, A., Angot, H., Artz, R., Brooks, S., Brunke, E.-G., Conley, G., Dommergue, A., Ebinghaus, R., Holsen, T., Jaffe, D., Kang, S., Kelley, P., Luke, W., Magand, O., Marumoto, K., Pfaffhuber, K., Ren, X., Sheu, G.-R., Slemr, F., Warneke, T., Weigelt, A., Weiss-Penzias, P., Wip, D., and Zhang, Q.: Top-down constraints on atmospheric mercury emissions and implications for global biogeochemical cycling, Atmos. Chem. Phys., 15, 7103-7125, https://doi.org/10.5194/acp15-7103-2015, 2015.

Sprovieri, F., Pirrone, N., Ebinghaus, R., Kock, H., and Dommergue, A.: A review of worldwide atmospheric mercury measurements, Atmos. Chem. Phys., 10, 8245-8265, https://doi.org/10.5194/acp-10-8245-2010, 2010.
Sprovieri, F., Pirrone, N., Bencardino, M., D’Amore, F., Carbone, F., Cinnirella, S., Mannarino, V., Landis, M., Ebinghaus, R., Weigelt, A., Brunke, E.-G., Labuschagne, C., Martin, L., Munthe, J., Wängberg, I., Artaxo, P., Morais, F., de Melo Jorge Barbosa, H., Brito, J., Cairns, W., Barbante, C., del Carmen Diéguez, M., Garcia, P. E., Dommergue, A., Angot, H., Magand, O., Skov, H., Horvat, M., Kotnik, J., Read, K. A., Neves, L. M., Gawlik, B. M., Sena, F., Mashyanov, N., Obolkin, V., Wip, D., Feng, X. B., Zhang, H., Fu, X., and Ramachan, R.: Atmospheric mercury concentrations observed at groundbased monitoring sites globally distributed in the framework of the GMOS network, Atmos. Chem. Phys., 16, 11915-11935, https://doi.org/10.5194/acp-16-11915-2016, 2016.

Steffen, A., Douglas, T., Amyot, M., Ariya, P., Aspmo, K., Berg, T., Bottenheim, J., Brooks, S., Cobbett, F., Dastoor, A., Dommergue, A., Ebinghaus, R., Ferrari, C., Gårdfldt, K., Goodsite, M., Lean, D., Poulain, A., Scherz, C., Skov, H., Sommar, J., and Temme, C.: A synthesis of atmospheric mercury depletion event chemistry in the atmosphere and snow, Atmos. Chem. Phys., 8, 1445-1482, https://doi.org/10.5194/acp-8-1445-2008, 2008.

Stein, A., Draxler, R., Rolph, G., Stunder, B., Cohen, M., and, F. N.: NOAA's HYSPLIT Atmospheric Transport and Dispersion Modeling System, Bull. Am. Meteorol. Soc., 96, 2059-2077, https://doi.org/10.1175/BAMS-D-14-00110.1, 2015.

United Nations Environment Programme (UNEP): Sources, Emissions, Releases and Environmental Transport, UNEP Chemicals Branch, Geneva, Switzerland, 42, 32 pp., 2013.

Wang, F., Saiz-Lopez, A., Mahajan, A., Gómez Martin, J., Armstrong, D., Lemes, M., Hay, T., and Prados-Roman, C.: Enhanced production of oxidised mercury over the tropical Pacific Ocean: a key missing oxidation pathway, Atmos. Chem. Phys., 14, 13231335, https://doi.org/10.5194/acp-14-1323-2014, 2014.

Whittlestone, S. and Zahorowski, W.: Baseline radon detectors for shipboard use: Development and deployment in the First Aerosol Characterization Experiment (ACE 1), J. Geophys. Res.-Atmos., 103, 16743-16751, https://doi.org/10.1029/98JD00687, 1998.

Williams, A. G., Chambers, S. D., Conen, F., Reimann, S., Hill, M., Griffiths, A. D., and Crawford, J.: Radon as a tracer of atmospheric influences on traffic-related air pollution in a small inland city, Tellus B, 68, 21 pp., https://doi.org/10.3402/tellusb.v68.30967, 2016.

Zahorowski, W., Griffiths, A., Chambers, S., Williams, A., Law, R., Crawford, J., and Werczynski, S.: Constraining annual and seasonal radon-222 flux density from the Southern Ocean using radon-222 concentrations in the boundary layer at Cape Grim, Tellus B, 65, 18 pp., https://doi.org/10.3402/tellusb.v65i0.19622, 2013.

Ziehn, T., Law, R., Rayner, P., and Roff, G.: Designing optimal greenhouse gas monitoring networks for Australia, Geoscientific Instrumentation Methods and Data Systems, 5, 1-15, https://doi.org/10.5194/gi-5-1-2016, 2016. 